\title{
Neurite Promoting Activity of Collagens on Embryonic Neurons: Decreased Effect at the Postnatal Stage
}

\author{
Hideki Hirose*, $\dagger$, Tetsuo Kitaguchi* and Takeshi \\ TABIRA* \\ *Division of Demyelinating Disease and Aging, National \\ Institute of Neuroscience, NCNP, Kodaira 18\%, and \\ $\dagger$ Research Laboratory, Nitta Gelatin Inc., Yao, Osaka 581
}

\begin{abstract}
Hirose, H., Kitaguchi, T. and Tabira, T. Neurite Promoting Activity of Collagens on Embryonic Neurons: Decreased Effect at the Postnatal Stage. Tohoku J. Exp. Med., 1993, 170 (4), 207-218 — We studied the in vitro neurite outgrowth activity of fibronectin, laminin, heparan sulfate proteoglycan, type I collagen, type IV collagen, and type VIII collagen in cholinergic neuronal cell lines and primary cultured neurons. All these substances had high neurite promoting activity on primary cultured neurons from embryonic mouse brain. However, collagens had no such an effect on primary cultured neurons from postnatal brain. When neuronal cell lines were used, collagens and other extracellular matrix substances were equally and highly effective on cells originated from embryonic brain, but collagens were less effective on cells from postnatal brain. These findings suggest that postnatal neurons lose the neuritic responsiveness to collagens earlier than that of other ECM. —— collagen; culture; extracellular matrix; neuron
\end{abstract}

The development of the nervous system involves generation of neuronal cells, cell migration, neurite outgrowth, and synapse formation within a complex and dynamic extracellular environment. It is now clear that interactions with the extracellular matrix (ECM) influence neuronal development, differentiation, and regeneration. In this context, several major constituents of the ECM, e.g., fibronectin (FN), laminin, and proteoglycans, have been extensively studied in the nervous system. FN, a cell-surface and serum-derived glycoprotein of molecular weight (MW) 440,000, can promote the adhesion, spreading, and migration of fibroblasts and certain other cells, including neuronal cells. FN enhances the capacity to support retinal neurite outgrowth (Akers et al. 1981), and local differences in FN concentration and availability in the matrix could be involved

Received May 31, 1993; revision accepted for publication June 20, 1993.

Address for reprints: Takeshi Tabira, Division of Demyelinating Disease and Aging, National Institute of Neuroscience, NCNP, 4-1-1 Ogawahigashi, Kodaira, Tokyo 187, Japan. 
in the direction of neural crest cell migration by serving as a chemoattractant (Newgreen and Thiery 1980; Greenberg et al. 1981). Furthermore, FN promotes the adhesion of Schwann cells, and stimulates their proliferation and migration (Baron-Van Evercooren et al. 1982).

Laminin (LN), a high molecular weight glycoprotein, of MW 850,000 or greater, has been found in basement membrane throughout the body. Many studies have indicated an association between neuronal cells and LN. LN is a potent stimulator for neurite elongation of cultured neurons obtained from both central and peripheral neuronal tissues (Manthorpe et al. 1983; Rogers et al. 1983), and substrate-bound LN pathways guide the neurites of central and peripheral neurons (Hammarback et al. 1985, 1988). LN is concentrated in astrocytes, schwannoma cells, and Schwann cells in culture (Liesi et al. 1983; Palm and Furcht 1983; Chiu et al. 1991). It has also been shown that LN may be available on the cell surface and in the extracellular space as an adhesive ligand for growth cones during the formation of the ventral longitudinal pathway (Letourneau et al. 1988).

Proteoglycans are proteins that carry one or more glycosaminoglycan side chains; it has recently been reported that chondroitin sulfate proteoglycan and heparan sulfate proteoglycan (HSPG) are associated with the nervous system (Aquino et al. 1984; Ratner et al. 1985; Hantaz-Ambroise et al. 1987; Bertolotto et al. 1990; Carey et al. 1990; Herndon and Lander 1990; Sheppard et al. 1991).

Collagen (COL) is by far the most common constituent of the connective tissue and is ubiquitously distributed in the body. It plays an important role in cell proliferation, morphogenesis, and in the expression and maintenance of functional differentiation. However, there is a paucity of information regarding whether COL has any effect on neurons in the central nervous system, COL not generally being observed in the brain, except in the perivascular areas and meninges. Accordingly, we studied the effects of ECM constituents on the development of central cholinergic neuronal cell lines and primary cultured cerebral neurons, using an in vitro neurite outgrowth assay. We found that COL has a high neurite-promoting activity in cells from prenatal mouse brain, whereas it has little effect on the neurite outgrowth of postnatal neurons.

\section{Materials and Methods}

\section{ECM constituents}

Of the ECM constituents used in the present study, type I collagen (COL-1), type IV collagen (COL-IV), and FN were kindly provided by Nitta Gelatin Inc. (Osaka). LN and HSPG, listed as "Extracellular Matrix, Human," were purchased from Collaborative Research, Inc. (Two Oak Park, Bedford, UK), and poly-L-lysine (PLL) was obtained from Sigma Chemical Co. (St. Louis, MO, USA). Type VIII collagen (COL-VIII) (Sawada et al. 1990) was a kind gift from Dr. Konomi at the Division of Mental Retardation and Birth Defect Research, National Institute of Neuroscience (Kodaira, Tokyo). 


\section{Preparation of culture dishes coated with ECM constituents}

Two $\mathrm{ml}$ of $0.9 \% \mathrm{NaCl}$ solution, containing $10 \mu \mathrm{g} / \mathrm{ml}$ of PLL, was placed in a 35-mm plastic tissue culture dish (Falcon, Lincoln Park, NJ, USA). The dishes were incubated at room temperature for $2-4 \mathrm{hr}$, and then rinsed twice with $0.9 \% \mathrm{NaCl}$ solution to remove free PLL. Next, the PLL-coated dishes (PLL-dishes) were coated again with each ECM constituents under the conditions described below according to the manufacturer's information for optimal doses.

Types I, IV, and VIII collagens. A PLL-dish containing $2 \mathrm{ml}$ of $100 \mu \mathrm{g} / \mathrm{ml}$ COL-I (porcine), COL-IV (bovine), or COL-VIII (bovine) solution was incubated at $4^{\circ} \mathrm{C}$ overnight. The COL-I-, COL-IV-, or COL-VIII-coated dishes (COL-I-, COL-IV, or COL-VIII-dishes)

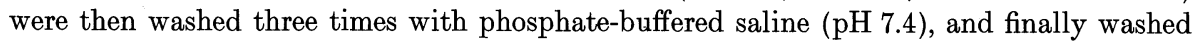
with serum-free medium.

Fibronectin. A PLL-dish containing $2 \mathrm{ml}$ of $3 \mu \mathrm{g} / \mathrm{ml} \mathrm{FN}$ (porcine) was incubated at $37^{\circ} \mathrm{C}$ overnight. The $\mathrm{FN}$-coated dishes (FN-dishes) were washed with serum-free medium just before use.

Laminin. A PLL-dish containing $1 \mathrm{ml}$ of $10 \mu \mathrm{g} / \mathrm{ml} \mathrm{LN}$ (murine) was incubated at room temperature for $1 \mathrm{hr}$. The LN-coated dishes (LN-dishes) were washed with serum-free medium just before use.

Heparan sulfate proteoglycan. A PLL-dish containing $1.25 \mathrm{ml}$ of $10 \mu \mathrm{g} / \mathrm{ml} \mathrm{HSPG}$ (human) was incubated at roon temperature for $2 \mathrm{hr}$. The HSPG-coated dishes (HSPGdishes) were washed with serum-free medium just before use.

\section{Cell lines}

We used several cell lines that retained cholinergic neuronal characteristics for our experiments; the cell lines were SN6, SN49, SN50, and SN52 neuronal hybridomas, and all were kindly provided by Dr. B.H. Wainer at the University of Chicago, Chicago. The SN6 cell line was established by somatic cell fusion of N18TG2 neuroblastoma and septal neurons obtained from C57BL/6 mouse brain at embryonic day 14 (ED14) (Hammond et al. 1986). The SN49, SN50 and SN52 cell lines were established similarly from the brains of postnatal day 21 (PD21) C57BL/6 mice (Lee et al. 1990).

All cell lines were grown on 100-mm plastic tissue culture dishes (Falcon) in a medium consisting of 90\% Dulbecco's modified Eagle medium ( $\mathrm{pH} \mathrm{7.2,} \mathrm{Gibco,} \mathrm{Grand} \mathrm{Island,} \mathrm{NY,}$ USA), $10 \%$ heat-inactivated fetal bovine serum (Gibco), $100 \mu \mathrm{g} / \mathrm{ml}$ streptomycin, and 100 units/ml penicillin (Gibco). Cells were dissociated for replating by vigorous trituration, and the growth medium was replaced twice a week. All cultures were maintained at $37^{\circ} \mathrm{C}$ in a humidified air atmosphere containing $5 \% \mathrm{CO}_{2}$.

In the following experiments for assay of neurite-promoting activity, all tissue cultures were performed in serum-free conditions, as described below. The serum-free supplemented medium (Kamegai et al. 1990) was a 1: 1 mixture of Dulbecco's modified Eagle medium and Ham's F-12 (pH 7.4, Gibco) supplemented with $100 \mu \mathrm{g} / \mathrm{ml}$ human transferrin, $25 \mu \mathrm{g} / \mathrm{ml}$ bovine crystalline insulin, $7 \mathrm{ng} / \mathrm{ml}$ tocopherol, $7 \mathrm{ng} / \mathrm{ml}$ retinol, $100 \mu \mathrm{M}$ putrescine, $10 \mu \mathrm{M}$

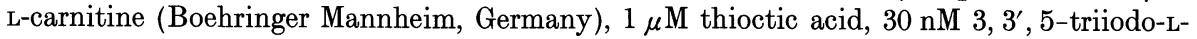
thyronine, $30 \mathrm{nM}$ sodium selenate (Wako Pure Chemical Industries, Ltd., Osaka), $20 \mathrm{nM}$ progesterone, $20 \mathrm{nM}$ hydrocortisone-21-phosphate, $1 \mu \mathrm{l} / \mathrm{ml} 1,000 \times$ mineral mixture solution (Hutchings and Sato 1978), $100 \mu \mathrm{g} / \mathrm{ml}$ streptomycin, and $100 \mathrm{units} / \mathrm{ml}$ penicillin. All supplements, except for L-carnitine, sodium selenate, and the mineral mixture, were purchased from Sigma Chemical Co.

\section{Primary culture of neuronal cells}

The primary culture of neuronal cells was prepared according to the method described (Hirose et al. 1993). Briefly, brains were obtained from BALB/cAJcl mice (Clea Japan, Tokyo) on ED14 or PD3. The cerebral hemispheres were dissected in Hanks' balanced salt 
solution ( $\mathrm{pH} 7.4$, Gibco), minced, and digested with $0.03 \%$ trypsin (Sigma) and 100 units/ $\mathrm{ml}$ deoxyribonuclease I (Sigma) in Hanks' balanced salt solution for 5 min at $37^{\circ} \mathrm{C}$. After gentle trituration through a pasteur pipette, the reaction was stopped by adding trypsin inhibitor (Sigma). The dispersed cells were washed twice in Hanks' balanced salt solution, filtered through a nylon screen (pore size $63 \mu \mathrm{m}$ ), suspended in the serum-free supplemented medium. Under these conditions, the amount of glial fibrillary acidic protein-positive cells was less than $4 \%$ at $120 \mathrm{hr}$ after the initiation of culture.

The culture was initiated at a density of $1 \times 10^{5}$ cells per 35 -mm culture dish for the study of neurite outgrowth of embryonic mouse neurons, and at a density of $5 \times 10^{5}$ cells per $35-\mathrm{mm}$ culture dish for the study of neurons derived from postnatal mouse brains. For the maintenance of primary cultured neurons from postnatal mouse brain, we used the serumfree supplemented medium containing $1 \mathrm{mg} / \mathrm{ml}$ bovine serum albumin (bovine fraction $\mathrm{V}$, Sigma).

\section{Assay of neurite-promoting activity}

Neurite-promoting activity was assessed as the proportion of neurite-bearing cells in the total number of cells in a culture. Neurites were difined as processes that exceeded one cell diameter in length. To confirm that these processes are neuronal origin, we performed immunostaining with monoclonal antibody to neurofilament polypeptide $200 \mathrm{kDa}$ (NE14, Boehringer Mannheim, Germany). As shown in Fig. 1, most of the processes were stained

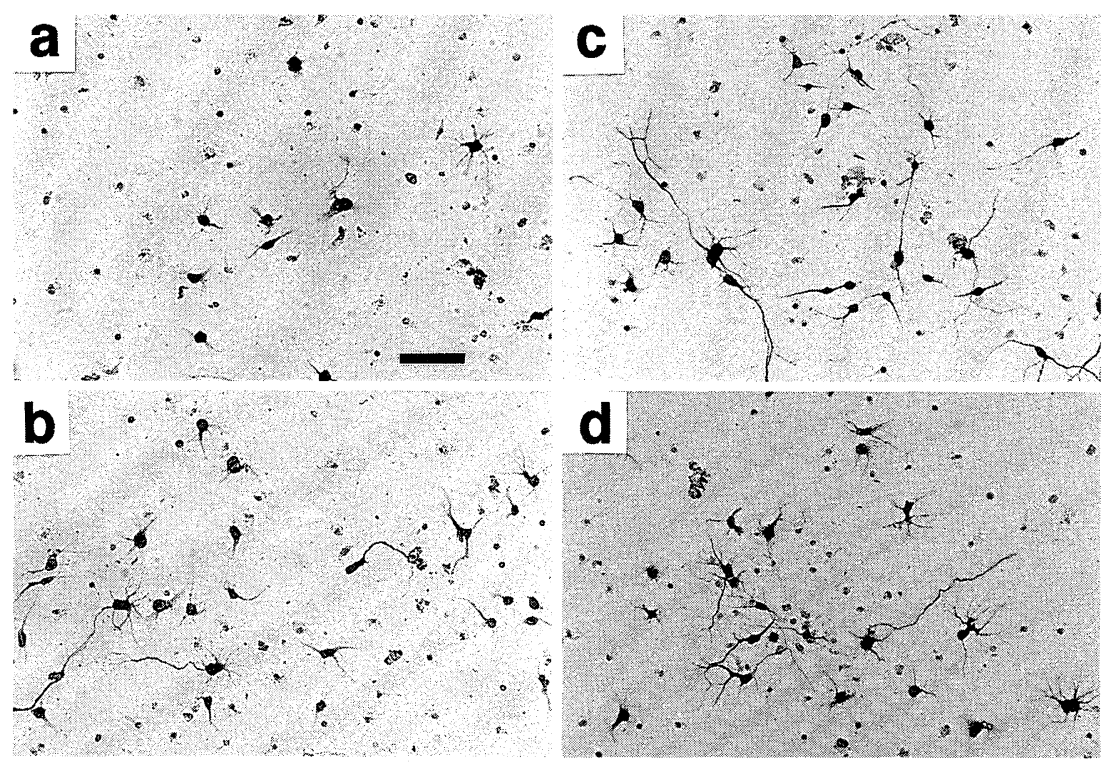

Fig. 1. Immunocytochemical staining of neurofilament in primary cultured neurons derived from prenatal mouse brain maintained $120 \mathrm{hr}$ on PLL- (a), FN-(b), LN-(c), and COL-I-dishes (d). The cultures were fixed with $4 \%$ paraformaldehyde in PBS, $\mathrm{pH} \mathrm{7.4,} \mathrm{for} 1 \mathrm{hr}$ at $4{ }^{\circ} \mathrm{C}$, and incubated with $0.2 \%$ Triton X-100 for $30 \mathrm{~min}$ at $37^{\circ} \mathrm{C}$. Cultures were rinsed with PBS three times for $10 \mathrm{~min}$ each. For the following steps, the cultures were worked according to the "step by step procedure" outlined in the instruction manual included in the Immunoperoxidase Staining Kit (Biomeda Corp., Foster City, CA, USA). The first antibody was a monoclonal antibody to neurofilament polypeptide $200 \mathrm{kDa}$. Bar, $50 \mu \mathrm{m}$. 
with this antibody.

Cells of the SN6, SN49, SN50, and SN52 cell lines were washed twice with phosphatebuffered saline and then exposed to $0.025 \%$ trypsin (Difco, Detroit, MI, USA) and $0.02 \%$ EDTA (Wako) in phosphate buffered saline. After incubation at $37^{\circ} \mathrm{C}$ for $3-5 \mathrm{~min}, 10 \mathrm{ml}$ of Dulbecco's modified Eagle medium containing 1\% heat-inactivated fetal bovine serum was added. The cell suspensions were then centrifuged, pelleted, and washed three times in $10-20 \mathrm{ml}$ of Hanks' balanced salt solution. Following the third wash, the cells were resuspended in the defined serum-free medium. The cell suspensions were then plated at $5 \times 10^{4}$ cells per 35 -mm tissue culture dish that had been coated beforehand with PLL alone or with PLL and an ECM constituent, following which they were incubated as described above.

Phase-contrast photomicrographs were taken randomly at 12,24 , and $48 \mathrm{hr}$ (and in addition, at 72 and $120 \mathrm{hr}$ for some experiments) after the initiation of culture. Neuritebearing cells in each culture were counted on three randomly-taken photographic prints at a final magnification of $160 \mathrm{x}$; all experiments were performed in duplicate cultures. Total cell numbers counted were 100-400 for neuronal cell lines, 100-200 for primary culture cells from embryonic mouse brain, and 400-700 for primary culture cells from postnatal mouse brain. Statistical analysis was done by the two-tailed student $t$-test.

\section{RESULtS}

Effects of ECM constituents on neurite outgrowth of SN6, a cell line derived from prenatal (ED14) mouse brain

In uncoated dishes (control) and PLL-dishes, very few SN6 cells extended neurites, and those that did showed difficulty of maintenance over $48 \mathrm{hr}$ in culture; the percentage of neurite-bearing cells was $6.2 \%$ at $24 \mathrm{hr}$ for both control and PLL. The percentage of neurite-bearing cells in FN-dishes increased steadily, reaching $26.6 \%$ at $48 \mathrm{hr}$ of culture. In LN-, HSPG-, COL-I-, COL-IV-, and COL-VIII-dishes, the percentages of neurite-bearing cells were highest at $24 \mathrm{hr}$ $(26.9 \%, 37.4 \%, 25.5 \%, 25.0 \%$, and $30.6 \%$, respectively), and they decreased slightly at $48 \mathrm{hr}$ (Fig. 2). Thus, in all cultures the percentage of neurite-bearing cells was significantly higher than PLL.

Effects of ECM constituents on neurite outgrowth of SN49, SN50, and SN52, cell lines derived from postnatal (PD21) mouse brain

In SN49 cells, the percentages of neurite-bearing cells of control and PLLdishes were $11.6 \%$ and $9.8 \%$, respectively, at $12 \mathrm{hr}$. In all cultures with FN, LN, HSPG, COL-I, COL-IV, and COL-VIII, the maximal percentages of neuritebearing cells were observed at 12 or $24 \mathrm{hr}(31.3 \%, 58.3 \%, 47.3 \%, 25.0 \%, 30.3 \%$, and $28.4 \%$, respectively), and they were slightly reduced thereafter (Fig. 3). LN and HSPG showed highest neurite-promoting activity with SN49. On the other hand, the percentages of neurite-bearing cells in cultures with the three types of COL were also higher than those in the control and PLL-dishes, but were significantly lower than those in LN and HSPG dishes (Fig. 3). Thus, the three types of COL had less neurite-promoting activity than the other ECM constituents 

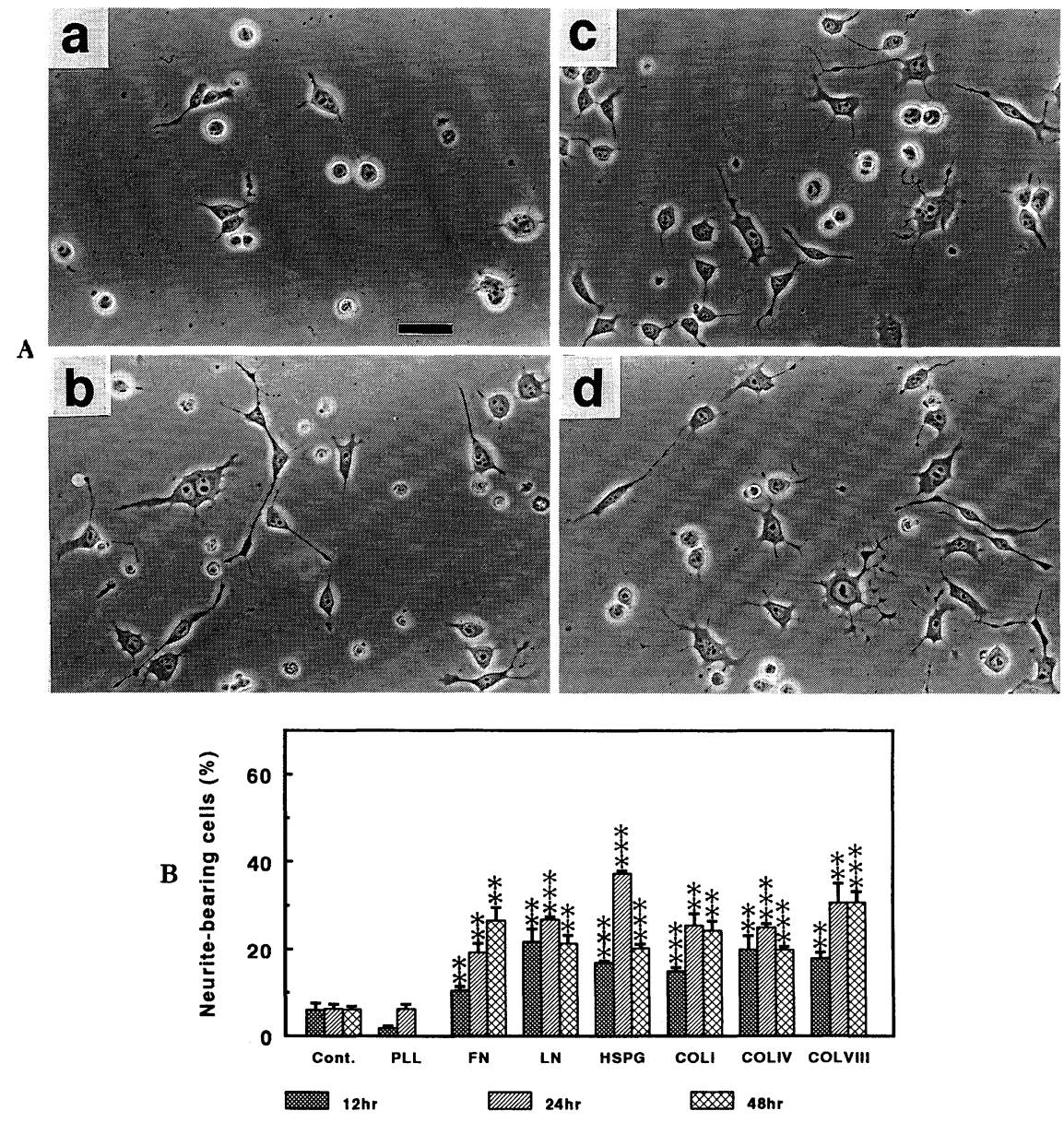

Fig. 2. The promotion of neurite outgrowth of SN6 cells. A: SN6 cells maintained on normal culture dishes were dissociated with $0.025 \%$ trypsin and $0.02 \%$ EDTA in PBS and the cells were seeded on PLL-, LN-, COL-I-, or COL-IV-dishes in serum-free supplemented medium. Phase-contrast micrographs $(160 \times)$ were taken $24 \mathrm{hr}$ after seeding. Cells plated on PLL-dishes (a) extend very few neurites, whereas cells plated on two kinds of COL-coated (c and d) dishes exhibit their neurites as long as those exhibited with LN (b). Bar, $50 \mu \mathrm{m}$. B: Data are expressed as means and S.D. of the percentage of neurite-bearing cells examined at 12,24 , and $48 \mathrm{hr}$ of culture. Statistic analyses were done against PLL at 12 and $24 \mathrm{hr}$ and Control at $48 \mathrm{hr} . \quad{ }^{*}, p<$ $0.05 ;{ }^{* *}, p<0.01 ;{ }^{* * *}, p<0.001$.

\section{with SN49.}

We also studied the neurite-promoting activity of ECM constituents with the SN50 and SN52 cell lines. The percentages of neurite-bearing cells in SN50 were generally lower than those in SN49. (The highest percentage was $23.6 \%$ at $12 \mathrm{hr}$ with LN). In FN-, LN-, and HSPG-dishes, the percentages of neurite-bearing 


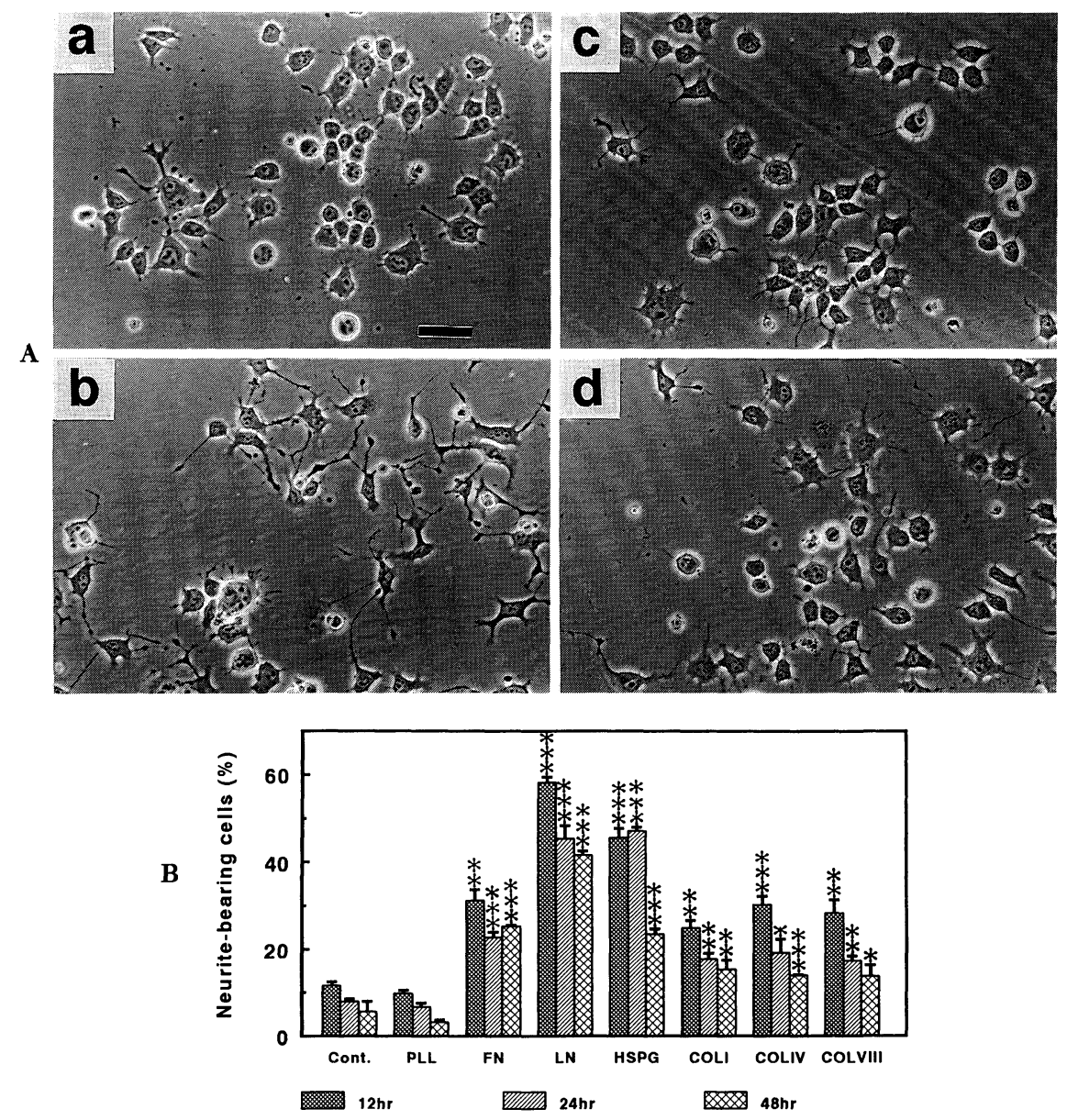

Fig. 3. The promotion of neurite outgrowth of SN49 cells. A: A few cells plated on PLL-dishes (a) extend neurites. The neurite-bearing cells seeded on COL-I (c) and COL-IV (d) are fewer than those on LN (b). Methods: see legend to Fig. 2A. Bar, $50 \mu \mathrm{m}$. B: Data are expressed as means and S.D. and statistic analysis were done all against PLL (see legend to Fig. 2B).

cells were $16.0-23.6 \%$ at $12 \mathrm{hr}$, which are significantly higher than those in control and PLL-dishes. In contrast, the percentages of neurite-bearing cells with COL-I and COL-IV were only 6.9 and $5.4 \%$, respectively (Table 1). Thus, COL had less neurite-promoting activity than the other ECM constituents with SN50. As shown in Table 1, the percentage of neurite-bearing cells decreased at the later time. This was also observed in SN49. Since the number of neurons increased at the later time, the decrease is due to the cell proliferation particularly with FN, LN and HSPG.

The percentages of neurite-bearing cells in the SN52 cell line were even lower than those in SN50. (The highest percentage was $14.6 \%$ at $12 \mathrm{hr}$ with FN.) In 
TABLE 1. Effects of ECM constituents on neurite outgrowth of SN50

\begin{tabular}{ccrrrrrr}
\hline $\begin{array}{c}\text { Culture time } \\
(\mathrm{hr})\end{array}$ & Control & PLL & FN & LN & HSPG & COL-I & COL-IV \\
\hline 12 & 5.8 & 2.2 & 16.0 & 23.6 & 19.8 & 6.9 & 5.4 \\
24 & 4.9 & 0.5 & 16.0 & 18.1 & 16.7 & 12.4 & 13.1 \\
48 & 4.7 & 1.5 & 8.4 & 10.4 & 10.7 & 12.8 & 10.8 \\
\hline
\end{tabular}

Data are expressed as \% of neurite-bearing cells.

FN-, LN-, and HSPG-dishes, the percentages of neurite-bearing cells were about 4 times higher than those in control and PLL-dishes. In contrast, the percentages of neurite-bearing cells with COL-I and COL-IV were about two times higher than those with control and PLL (data not shown). Again, the COL had less neurite-promoting activity than the other ECM constituents with SN52 cell line.

These findings led us to speculate that COL had less effect on the neurite outgrowth of neurons from postnatal mouse brains than on neurite outgrowth in the neurons derived from prenatal brains. To confirm this, we performed further experiments with primary cultured neurons.

Effects of ECM constituents on neurite outgrowth of primary cultured neurons derived from prenatal (ED14) mouse brain

In PLL-dishes, very few primary cultured cells had neurites, the percentage being $9.9 \%$ at $12 \mathrm{hr}$. In all cultures with FN, LN, HSPG, COL-I, COL-IV, and COL-VIII, the percentages of neurite-bearing cells at $48 \mathrm{hr}$ of culture were $46.9 \%$, $67.4 \%, 60.1 \%, 54.0 \%, 43.8 \%$, and $45.6 \%$, respectively (Fig. 4 ). Further, the percentages increased steadily with time up to $120 \mathrm{hr}$. Thus, all ECM constituents showed significantly higher neurite-promoting activity than PLL.

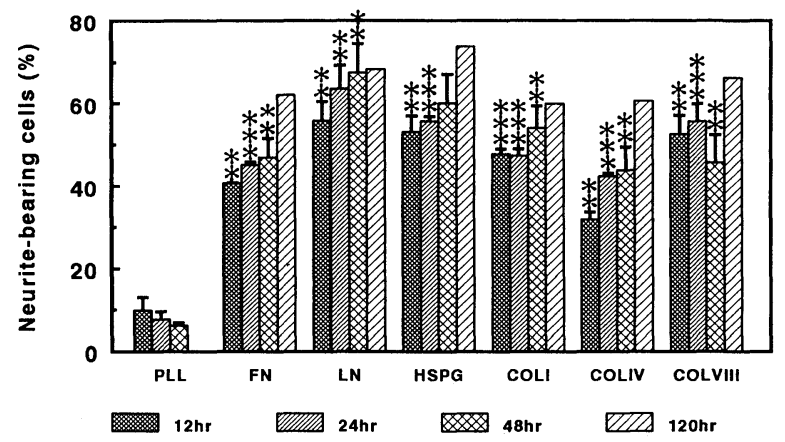

Fig. 4. The effect of ECM on neurite outgrowth of primary cultured neurons derived from prenatal mouse brain. The neurons prepared according to Experimental Procedures were seeded on ECM-coated dishes in serum-free supplemented medium. Data are expressed as means and S.D. and statistic analyses were done against PLL (see legend to Fig. 2B). 
Effects of ECM constituents on neurite outgrowth of primary cultured neurons derived from postnatal (PD3) mouse brain

In PLL-dishes, the percentage of neurite-bearing cells was $29.4 \%$ at $24 \mathrm{hr}$. This was higher than that of ED14 neurons (Fig. 4), because PD3 enurons had already had more neurites at the start of culture. In all cultures with FN, LN, HSPG, COL-I, and COL-IV, the maximal percentages of neurite-bearing cells were observed at either 12 or $24 \mathrm{hr}(38.3 \%, 37.1 \%, 43.5 \%, 26.8 \%$, and $28.4 \%$, respectively), and they decreased significantly thereafter (Fig. 5).

In FN-, LN-, and HSPG-dishes, the percentage of neurite-bearing cells were significantly higher than that in PLL-dishes at $48 \mathrm{hr}$. In contrast, the percentages of neurite-bearing cells in COL-I- and COL-IV-dishes appeared to be lower and were closer to those in PLL-dishes. Thus, COL had less neurite-promoting activity with the primary cultured neurons derived from postnatal mouse brains than the primary cultured neurons derived from prenatal brain.

\section{Discussion}

We examined the neutite-promoting activity of ECM constituents on cholinergic nuronal cell lines and primary cultured neurons. We found that PLL, which is commonly used as a substrate for neuronal cell culture, did not show neurite-promoting activity with any of the four cholinergic cell lines. However, all of the ECM constituents but PLL had specific neurite-promoting activity with these neuronal cells.

When SN6 was used, all the ECM constituents were equally effective. However, when SN49 was used, LN and HSPG had highest neurite promoting activity, but collagens were less effective. Since SN49 is more differentiated, the

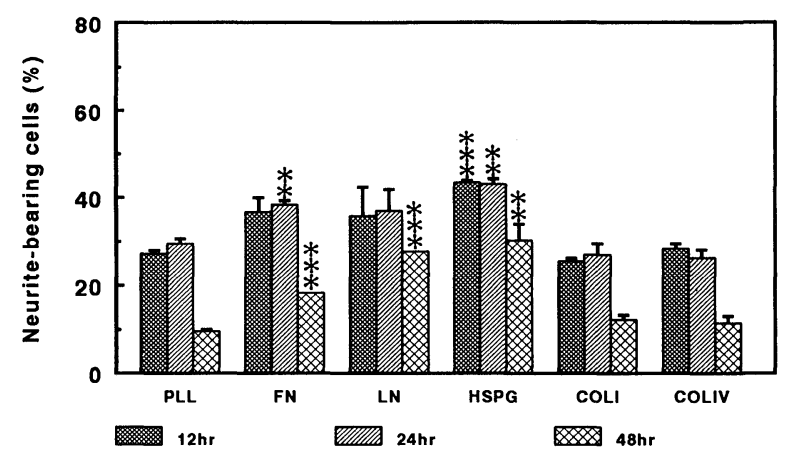

Fig. 5. The effect of ECM on neurite outgrowth of primary cultured neurons derived from postnatal mouse brain. The neurons prepared according to Materials AND MEthods were seeded on ECM-coated dishes in serum-free supplemented medium containing $1 \mathrm{mg} / \mathrm{ml}$ bovine serum albumin. Data are expressed as means and S.D. and statistic analyses were done against PLL (see legend to Fig. 2B). 
response to $\mathrm{LN}$ and HSPG was expectedly high. Therefore, we judged that responses to collagens were rather decreased. It is most interesting to note, therefore, that the neurite-promoting activity of COL differed according to the stage of neuronal development. That is, COL-I, COL-IV, and COL-VIII had a significant neurite promoting activity with SN6, which is derived from prenatal mouse brain, while this activity was less in extent with $\mathrm{SN} 49,50$, and 52, which are derived from postnatal brain. These differences were particularly true with primary cultured neurons. Since other ECM constituents affected both prenatal and postnatal neurons equally, it would appear that this difference is characteristic of COL.

Although COL is a major component of the ECM in the body, its role in the development of the central nervous system has not been known. It has generally been thought that COL has little association with the nervous system in vivo. Recently, however, it has been found that COL serves as a substrate for neuronal crest cells to migrate in vitro (Greenberg et al. 1981; Perris et al. 1991). Attachment, flattening, and neurite outgrowth of PC12 cells and embryonic chicken sensory cells from dorsal root ganglia has been shown to occur in dishes coated with COL (Vlodavsky et al. 1982; Turner et al. 1989), and COL has been shown to play a role in pathway finding and growth cone guidance (Carbonetto et al. 1983; Tomaselli et al. 1987). It has also recently been shown that COL-IV is located within the developing central nervous system of Drosophila (Mirre et al. 1992), and further, two glial cell lines, C6 and 9L, have been shown to produce COL-I in vitro (Ghahary et al. 1992). Our results suggest that COL may contribute to the neurite extension of central nervous system neurons in the developing brain. To see its significance in vivo, it is necessary to study whether COLs are expressed in the developing central nervous system of the mammals.

\section{Acknowledgments}

We wish to thank Dr. B.H. Wainer at the University of Chicago for providing us with SN6, SN49, SN50, and SN52 cells, Dr. H. Konomi at this institute for his generous gift of COL-VIII, and Dr. K. Takahashi, Dr. T. Kunishita, Dr. T. Yamamura, and Dr. Y. Konishi in this division for their critical comments. This work was supported by a grant from the Science and Technology Agency of Japan.

\section{References}

1) Akers, R.M., Mosher, D.F. \& Lilien, J.E. (1981) Promotion of retinal neurite outgrowth by substratum-bound fibronectin. Dev. Biol., 86, 179-188.

2) Aquino, D.A., Margolis, R.U. \& Margolis, R.K. (1984) Immunocytochemical localization of a chondroitin sulfate proteoglycan in nervous tissue. II. Studies in developing brain. J. Cell Biol., 99, 1130-1139.

3) Baron-Van Evercooren, A., Kleinman, H.K., Seppä, H.E.J., Rentier, B. \& DuboisDalcq, M. (1982) Fibronectin promotes rat Schwann cell growth and motility. $J$. Cell Biol., 93, 211-216.

4) Bertolotto, A., Rocca, G. \& Schiffer, D. (1990) Chondroitin 4-sulfate proteoglycan 
forms an extracellular network in human and rat central nervous system. J. Neurol. Sci., 100, 113-123.

5) Carbonetto, S., Gruver, M.M. \& Turner, D.C. (1983) Nerve fiber growth in culture on fibronectin, collagen and glycosaminoglycan substrates. J. Neurosci., 3, 2324-2325.

6) Carey, D.J., Crumbling, D.M., Stahl, R.C. \& Evans, D.M. (1990) Association of cell surface heparan sulfate proteoglycans of Schwann cells with extracellular matrix proteins. J. Biol. Chem., 265, 20627-20633.

7) Chiu, A.Y., Espinosa de lon Monteros, A., Cole, R.A., Loera, S. \& de Vellis, J. (1991) Laminin and s-laminin are produced and released by astrocytes, Schwann cells, and Schwannomas in culture. Glia, 4, 11-24.

8) Ghahary, A., Bhatnagar, R., Price, K., Forsyth, N.L., Shen, Y.J., Tredget, T.E. \& Malhotra, S.K. (1992) Rat glioma cell lines C6 and 9L synthesize type 1 collagen in vitro. Brain Res. Bull., 28, 47-56.

9) Greenberg, J.H., Seppä, S., Seppä, H. \& Hewitt, A.T. (1981) Role of collagen and fibronectin in neural crest cell adhesion and migration. Dev. Biol., 87, 259-266.

10) Hammarback, J.A., Palm, S.L., Furcht, L.T. \& Letourneau, P.C. (1985) Guidance of neurite outgrowth by pathways of substratum-adsorbed laminin. J. Neurosci. Res., 13, 213-220.

11) Hammarback, J.A., McCarthy, J.B., Palm, S.L., Furcht, L.T. \& Letourneau, P.C. (1988) Growth cone guidance by substrate-bound laminin pathways is correlated with neuron-to-pathway adhesivity. Dev. Biol., 126, 29-39.

12) Hammond, D.N., Wainer, B.H., Tonsgard, J.H. \& Heller, A. (1986) Neuronal properties of clonal hybrid cell lines derived from central cholinergic neurons. Science, 234, 1237-1240.

13) Hantaz-Ambroise, D., Vigny, M. \& Koenig, J. (1987) Heparan sulfate proteoglycan and laminin mediate two different types of neurite outgrowth. J. Neurosci., 7, 22932304.

14) Herndon, M.E. \& Lander, A.D. (1990) A diverse set of developmentally regulated proteoglycans is expressed in the rat central nervous system. Neuron, 4, 949-961.

15) Hirose, H., Kitaguchi, T. \& Tabira, T. (1993) Enriched cultures of differentiated neurons from mouse embryo whole brain by using extracellular matrix constituents. $J$. Tissue Culture Methods, in press.

16) Hutchings, S.E. \& Sato, G.H. (1978) Growth and maintenance of Hela cells in serum-free medium supplemented with hormones. Proc. Natl. Acad. Sci. USA, 75, 901-904.

17) Kamegai, M., Niijima, K., Kunishita, T., Nishizawa, M., Ogawa, M., Araki, M., Ueki, A., Konishi, Y. \& Tabira, T. (1990) Interleukin-3 as a trophic factor for central cholinergic neurons in vitro and in vivo. Neuron, 4, 429-436.

18) Lee, H.J., Hammond, D.N., Large, T.H. \& Wainer, B.H. (1990) Immortalized young adult neurons from the septal region: Generation and characterization. Dev. Brain Res., 52, 219-228.

19) Letourneau, P.C., Madsen, A.M., Palm, S.L. \& Furcht, L.T. (1988) Immunoreactivity for laminin in the devoloping ventral longitudinal pathway of the brain. Dev. Biol., 125, 135-144.

20) Liesi, P., Dahl, D. \& Vaheri, A. (1983) Laminin is produced by early rat astrocytes in primary culture. J. Cell Biol., 96, 920-924.

21) Manthorpe, M., Engvall, E., Ruoslahti, E., Longo, F.M., Davis, G.E. \& Varon, S. (1983) Laminin promotes neuritic regeneration from cultured peripheral and central neurons. J. Cell Biol., 97, 1882-1890.

22) Mirre, C., Le Parco, Y. \& Knibiehler, B. (1992) Collagen IV is present in the developing CNS during Drosophila neurogenesis. J. Neurosci. Res., 31, 146-155.

23) Newgreen, D. \& Thiery, J.P. (1980) Fibronectin in early avian embryos: Synthesis and distribution along the migration pathways of neural crest cells. Cell Tissue Res., 
211, 269-291.

24) Palm, S.L. \& Furcht, L.T. (1983) Production of laminin and fibronectin by Schwannoma cells: Cell-protein interactions in vitro and protein localization in peripheral nerve in vivo. J. Cell Biol., 96, 1218-1226.

25) Perris, R., Krotoski, D. \& Bronner-Fraser, M. (1991) Collagen in avian neural crest development: Distribution in vivo and migration-promoting ability in vitro. Development, 113, 969-984.

26) Ratner, N., Bunge, R.P. \& Glaser, L. (1985) A neuronal cell surface heparan sulfate proteoglycan is required for dorsal root ganglion neuron stimulation of Schwann cell proliferation. J. Cell Biol., 101, 744-754.

27) Rogers, S.L., Letourneau, P.C., Palm, S.L., McCarthy, J. \& Furcht, L.T. (1983) Neurite extension by peripheral and central nervous system neurons in response to substratum-bound fibronectin and laminin. Dev. Biol., 98, 212-220.

28) Sawada, H., Konomi, H. \& Hirosawa, K. (1990) Characterization of the collagen in the hexagonal lattice of Descemet's membrane: Its relation to type VIII collagen. $J$. Cell Biol., 110, 219-227.

29) Sheppard, A.M., Hamilton, S.K. \& Pearlman, A.L. (1991) Changes in the distribution of extracellular matrix components accompany early morphogenetic events of mammalian cortical development. J. Neurosci., 11, 3928-3942.

30) Tomaselli, K.J., Damsky, C.H. \& Reichardt, L.F. (1987) Interactions of a neuronal cell line (PC12) with laminin, collagen IV, and fibronectin: Identification of integrinrelated glycoproteins involved in attachment and process outgrowth. J. Cell Biol., $105,2347-2358$.

31) Turner, D.C., Flier, L.A. \& Carbonetto, S. (1989) Identification of a cell-surface protein involved in PC12 cell-substratum adhesion and neurite outgrowth on laminin and collagen. J. Neurosci., 9, 3287-8296.

32) Vlodavsky, I., Levi, A., Lax, I., Fuks, Z. \& Schlessinger, J. (1982) Induction of cell attachment and morphological differentiation in a pheochromocytoma cell line and embryonal sensory cells by the extracellular matrix. Dev. Biol., 93, 285-300. 